NBER WORKING PAPER SERIES

\title{
AUCTIONS WITH RESALE WHEN PRIVATE VALUES ARE UNCERTAIN: EVIDENCE FROM THE LAB AND FIELD
}

\author{
Andreas Lange \\ John A. List \\ Michael K. Price \\ Working Paper 16360 \\ http://www.nber.org/papers/w16360
}

\author{
NATIONAL BUREAU OF ECONOMIC RESEARCH \\ 1050 Massachusetts Avenue \\ Cambridge, MA 02138 \\ September 2010
}

This paper is a significantly revised version of NBER Working Paper No. 10639: Auctions with Resale When Private Values Are Uncertain: Theory and Empirical Evidence. Larry Ausubel, Peter Cramton, Glenn Harrison, Liesl Koch, and Tigran Melkonyan provided useful suggestions on an earlier version of this study and during the discovery process. Seminar participants at several universities provided comments that improved the manuscript. Andreas Lange gratefully acknowledges funding by the Deutsche Forschungsgemeinschaft (DFG) under grant LA 1333/2-1. The views expressed herein are those of the authors and do not necessarily reflect the views of the National Bureau of Economic Research.

NBER working papers are circulated for discussion and comment purposes. They have not been peerreviewed or been subject to the review by the NBER Board of Directors that accompanies official NBER publications.

(C) 2010 by Andreas Lange, John A. List, and Michael K. Price. All rights reserved. Short sections of text, not to exceed two paragraphs, may be quoted without explicit permission provided that full credit, including $\odot$ notice, is given to the source. 
Auctions with Resale When Private Values Are Uncertain: Evidence from the Lab and Field Andreas Lange, John A. List, and Michael K. Price

NBER Working Paper No. 16360

September 2010

JEL No. C9,C91,D03,D44

\begin{abstract}
$\underline{\text { ABSTRACT }}$
Auction theory represents one of the richest areas of research in economics over the past three decades. Yet, whether, and to what extent, the introduction of secondary resale markets influences bidding behavior in sealed bid first-price auctions remains under researched. This study begins by examining field data from a unique data set that includes nearly 3,000 auctions (over 10,000 individual bids) for cutting rights of standing timber in British Columbia from 1996-2000. In comparing bidding patterns across agents who are likely to have resale opportunities with those who likely do not, we find evidence that is consistent with theory. Critical evaluation of the reduced-form bidding model, however, reveals that sharp tests of the theoretical predictions are not possible because several other differences may exist across these bidder types. We therefore use a laboratory experiment to examine if the resale opportunity by itself can have the predicted theoretical effect. We find that while it does have the predicted effect, a theoretical model based on risk-averse bidders explains the overall data patterns more accurately than a model based on risk-neutral bidders. Beyond testing theory, the paper highlights the inferential power of combining naturally occurring data with laboratory data.
\end{abstract}

\author{
Andreas Lange \\ University of Maryland \\ 2200 Symons Hall \\ College Park, MD 20742 \\ and University of Hamburg, Germany \\ and also NBER \\ alange@arec.umd.edu \\ John A. List \\ Department of Economics \\ University of Chicago \\ 1126 East 59th \\ Chicago, IL 60637 \\ and NBER \\ jlist@uchicago.edu
}

\author{
Michael K. Price \\ Department of Economics \\ 515 Stokely Management Center \\ University of Tennessee, Knoxville \\ Knoxville, TN 37996 \\ mprice21@utk.edu
}




\section{Introduction}

Auctions have a long and storied history. From the human slave auctions carried out in ancient Egypt to the marriage auctions for brides in Asia Minor to the Praetorian Guard auctioning off the Roman Empire in A.D. 193, auctions have been used to allocate goods and services. While auctions have certainly served an important purpose throughout the history of mankind and are now used to sell almost anything one can imagine - vintage wines, Treasury bills, pollution permits, baseball cards, etc. - economists have only recently begun to explore rigorously the theoretical underpinnings of various auction formats (see Klemperer (1999) for a nice review).

A recent set of studies in the literature explores cases when individual valuations are not known with certainty at the time of the auction. ${ }^{1}$ Haile's (2003) work goes a step further by introducing secondary (resale) markets, creating an environment that represents many naturallyoccurring settings: U.S. Forest Service timber auctions, the procurement of governmental contracts, estate auctions, art auctions, FCC auctions and the like all fit in this general class of allocation mechanisms. ${ }^{2}$ Unlike the traditional auction literature that assumes independent private values (IPV) that are known with certainty, when bidders have ex ante uncertainty about independent private values and anticipate resale opportunities, equilibrium bidding strategies are dependent upon option values conveyed from the secondary market. Intuitively, bidder behavior in this case is linked to the existence and structure of potential resale markets.

\footnotetext{
${ }^{1}$ For example, it is well established in the literature that when bidders receive multi-dimensional or uncertain signals, auctions may generate inefficient allocations (Pesendorfer and Swinkels (2000), Jehiel and Moldovanu (2001), Goeree and Offerman (2003)). Efficiency and bidding strategies in such an environment are dependent upon the weight individual bidders assign to both the private and common value components of a signal and upon the number of participants in a given market. Other studies that relax the assumption of known valuations include the work of Schwarz and Sonin (2004) and Haile (2000).

${ }^{2}$ There is a growing theoretical literature that examines the impacts of such resale opportunities on bidder behavior and a seller's optimal choice of auction format (see, for example, Bikhchandani and Huang (1989), Gupta and Lebrun (1999), and Garratt and Troger (2006)). Experimentally the impact of resale opportunities on bidder behavior has been examined in the context of English auctions (Georganas, 2009) and in auctions with asymmetric bidders (Georganas and Kagel, 2009).
} 
Our study attempts to make empirical advances in this area. The empirical investigation begins by making use of naturally-occurring data drawn from nearly 3,000 timber auctions (over 10,000 individual bids) from the Small Business Forest Enterprise Program (SBFEP) for the interior region of British Columbia (BC) for the period 1996-2000. While our results are consonant with theory, a number of caveats and strong assumptions are necessary to identify the resale effect under our reduced-form modeling approach.

One way to approach this quandary is to make use of a laboratory experiment. By studying artificial markets that differ only in whether a secondary market is available, we are permitted a unique glimpse into whether the resale market by itself can lead to such predicted consequences. Keeping an eye toward designing a laboratory setting that resembles naturally occurring markets while maintaining a strong theoretical link, we designed an experiment using the first-price auction with both a second stage optimal auction (OA) as well as an English auction (EA) continuation game of complete information. ${ }^{3}$ Given that this is the first controlled experimental test in this area, our approach of using the extremes for the division of surplus on the secondary market is apropos since it allows a controlled test of existing theory and provides a useful benchmark for making inference from field data.

The lab results are broadly in line with theoretical predictions. First, we find that experimental subjects submit bids that are significantly higher in markets with resale organized by an optimal auction than in those without such opportunity (or with secondary markets organized by an EA). This result is intuitively appealing as one would expect subjects to bid more aggressively when winning an auction is more valuable. Second, we find differences in

\footnotetext{
${ }^{3}$ Our use of the optimal and English auction terminology follows Haile (2003) and reflects the extremes for the division of surplus on the secondary market. Under an OA continuation game, the resale seller receives maximal gains from secondary market trade. In contrast, the resale buyer receives maximal gains under the EA continuation game.
} 
baseline bids and those in our EA treatment that are consonant with theory: over lower (higher) ranges of the signal space bids in the EA treatment are greater than (less than) those submitted in our baseline no resale markets. This comparison represents a demanding test of theory, as it requires subjects to recognize and consider differences in the option values conveyed by resale over the signal space. Finally, an interesting data pattern not anticipated by extant theory is that over lower ranges of the signal space, realized bids are less than the risk-neutral theoretical predictions, while over higher ranges of the signal space, realized bids are greater than the riskneutral theoretical predictions. Yet, these tendencies are consonant with a theory with riskaverse bidders.

We view our study as contributing to our understanding of the effect of adding resale opportunities to auctions, and more generally furthering our knowledge concerning how secondary market structure affects bidder behavior. In addition, the study provides empirical evidence of behavior in such markets that can aid in the design and implementation of efficient mechanisms for the allocation of goods and services. Methodologically, our paper showcases the benefits of combining lab and field data to test economic theory and provide policy advice.

The remainder of the paper is crafted as follows. Section II provides an overview of the SBFEP auction market and our strategy for identifying resale differences using reduced-form bid functions. Section III discusses the laboratory experiment and results. Section IV concludes.

\section{The SBFEP Auction Market}

\section{The SBFEP Auction - Background and Predictions}

Our naturally occurring data are drawn from nearly 3,000 timber auctions (over 10,000 individual bids) from the Small Business Forest Enterprise Program for the interior region of British Columbia for the period 1996-2000. During our sample period, SBFEP auctions in BC 
were used to allocate standing timber of less than 50,000 metric board feet cubed $\left(\mathrm{mb}^{3}\right)$ to small logging companies and contractors. These auctions are subdivided into two types: Category 1 and Category 2, where Category 1 auctions include only market loggers. Category 2 auctions are open to both registered market loggers and registered owners of processing facilities.

Category 1 bidders purchase timber cutting rights and sell harvested timber to end users. In the interior of $\mathrm{BC}$ almost all harvested timber is sold to either major forest license holders or local sawmills. Ex ante, bidders contract with a prospective buyer to arrange an agreement in principle to sell/buy if they win the auction. The bidders then submit bids and the winner consummates the agreement in principle and chooses to lock in the stumpage price he bid. Category 2 bidders purchase timber cutting rights to obtain raw materials for their processing operations. Bidders either process harvested timber or trade it to obtain needed materials. ${ }^{4}$

Since processing facilities are actively engaged in the ex post buying and selling of harvested logs whereas loggers contract ex ante to deliver all harvest to a given buyer, resale might enter into the bidding strategies of the former but not the latter. Intuitively, since processing facilities have an outside option to sell logs on a spot market whereas loggers do not have such an option, one would expect that processing facilities would provide an upper envelope on the observed bids of loggers from the interior. To identify whether this effect holds, we rely upon cross sectional variation. ${ }^{5}$

Identifying Resale Effects from Reduced-Form Bid Functions

\footnotetext{
${ }^{4}$ Throughout the empirical analysis we assume that firms are symmetric. Since participation in the SBFEP is limited to loggers who do not own processing facilities and small sawmills, bidder asymmetry is less likely than in timber auctions in the United States (see e.g., Athey et al., 2004). Our identification strategy relies upon the symmetry assumption, and we should note that models which allow bidder asymmetry may generate different comparative static results.

${ }^{5}$ In this sense, our identification strategy is much different from Haile (2001), who analyzes individual bids from the U.S. timber auctions and makes use of the temporal variation in the imposition of federal regulations by examining bids prior to the onset of the regulations that effectively prohibited resale and comparing them to bids after the regulations took effect.
} 
Haile (2003) highlights two opposing effects of resale on bidder valuations and hence strategies - the resale seller effect (the option value of selling in the resale market) and the resale buyer effect (the option value of buying in the resale market). Intuitively, whenever the resale seller effect dominates, the expected value of winning any auction is a combination of an agent's private use value and the expected profits of selling on the secondary market. Provided that the expected profit of resale is non-zero, this option value leads to higher overall bids. Given the structure of secondary market exchange we expect the resale seller effect to be more pronounced amongst Category 2 bidders.

To identify this comparative static, we employ a general approach that is in the spirit of, for example, Porter and Zona (1993, 1999). We employ reduced-form methods to infer the nature of resale effects by differences in bidding patterns across subsets of firms facing different outside options. ${ }^{6}$ As the true equilibrium bidding function is unknown in practice, we consider two different specifications to approximate observed bidding behavior given by:

$$
\begin{gathered}
P_{i j}=X_{i j} \beta+\tau D_{i}+\varepsilon_{i j} \\
P_{i j}=D_{i}\left[X_{i j} \beta_{1}\right]+\left(1-D_{i}\right)\left[X_{i j} \beta_{0}\right]+\varepsilon_{i j}
\end{gathered}
$$

where $P_{i j}$ is the $i$ th bidder's total bid in auction $j . \quad X_{i j}$ is a set of regressors underlying the $i^{\text {th }}$ firm's valuation for tract $j, \mathrm{D}_{\mathrm{i}}$ is a dummy variable that equals one for any bid placed by a mill in a Category 2 auction; $\varepsilon_{i j}=\alpha_{i}+u_{i j} ; \mathrm{E}\left[\alpha_{i}\right]=0, \mathrm{E}\left[\alpha_{i}^{2}\right]=\sigma_{\alpha}^{2}, \mathrm{E}\left[\alpha_{i} \alpha_{k}\right]=0$ for $i \neq k ; \alpha_{i}$ and $u_{i j}$ are orthogonal for all $i$ and $j . \alpha_{i}$ is a random effect assumed to capture heterogeneity that would be

\footnotetext{
${ }^{6}$ An alternate approach to identifying resale effects would be to employ structural methods similar to those developed in Laffont et al. (1995) or Guerre et al. (2000). However, to use these methods, we would have to specify the structure of the resale market which is based upon bilateral exchange between mills that is unobserved in our data. Without being able to specify the nature of secondary market exchange, we could not identify the first-order conditions defining optimal bids which are fundamental to these structural methods.
} 
left uncontrolled in a standard cross-sectional model and $\mathrm{u}_{\mathrm{ij}}$ represents private information such as idiosyncratic shocks to the expected valuation for firm $i$ in auction $j$.

Specification (1) indicates that the effect of resale acts only as an intercept shift for mills in Category 2 auction, while (1') permits the resale effect to enter both the slope and intercept terms. Theoretically, if the resale seller effect dominates for Category 2 bids, then we would expect that $\hat{\tau}>0$ and $\hat{\beta}_{1} \neq \hat{\beta}_{0}$. In particular, we should observe that the estimated comparative static effect of competition (and any other covariate that is positively related with a bidder's private use value) on observed bids is smaller for interior Category 1 auctions than it is for otherwise equivalent Category 2 auctions generating predicted bids that are greater for the latter subset of auctions.

\section{The SBFEP Auction Data - Empirical Results}

We observe 2,671 SBFEP sealed-bid tender first-price auctions conducted in the interior of British Columbia for the period January 1996 through December 2002. ${ }^{7}$ These auctions provide more than 10,000 individual bids, from which we eliminate any bids submitted in auctions with only a single bidder, any bids submitted in an auction with an estimated net cruise volume of less than $1,000 \mathrm{~m}^{3}$, any bids submitted in an auction employing a format other than a first-price sealed tender, and any bids submitted by a bidder that participates in both Category 1 and Category 2 auctions. This results in a sample of nearly 1,250 firms that submit nearly 5,500 bids.

To generate the data for the empirical model, we combine information from a number of sources. First, a list of all bidders currently registered to participate in SBFEP timber auctions

\footnotetext{
${ }^{7}$ This is the identical data set that $\mathrm{BC}$ is using to test a new pricing approach under the changed circumstance agreement for the U.S.-Canadian softwood lumber dispute. See List, Millimet, and Price (2008) for a more detailed discussion of the trade dispute and the new pricing approach.
} 
was provided by the Ministry of Forests (MOF) in BC. This listing was used to generate unique identification codes for each bidder in the data set. Second, the MOF provided bid sheets for each auction that provides information on (i) the regional office holding and date of the auction, (ii) the estimated net cruise volume of timber on the plot, (iii) the announced upset rate for the auction, and (iv) the identity and bonus bid per $\mathrm{m}^{3}$ for each participant in the auction. Finally, the MOF provided a database that contains detailed information on the characteristics of each plot and the required deadline to complete the harvest of the specified timber. Table 1 summarizes these data.

To condition behavior on observed auction characteristics in tests for resale effects, we estimate a series of reduced-form bid functions. Specifically, we assume that equilibrium bidding behavior follows the linear specification in equation (1), and therefore estimate

$$
P_{i j}=\beta X_{i j}+\varepsilon_{i j},
$$

where all variables are as defined above. Auction covariates included in the vector of regressors include:

- UPSET RATE: announced reservation price per $\mathrm{m}^{3}$

- NCV: estimated net cruise volume (divided by 1000)

- VPH: estimated volume of trees per hectare (divided by 1000)

- LNVPT: log of estimated volume per tree

- LSPI: the average selling price index for timber harvested

- DC: deflated development costs (divided by NCV)

- SLOPE: weighted average slope

- BWDN: estimated percent of volume blown down

- BURN: estimated percent of volume burned 
- CY: estimated percent of volume to be extracted via cable

- HP: estimated percent of volume to be extracted via helicopter

- HORSE: estimated percent of volume to be extracted via horse

- UTIL: estimated capacity utilization for firm $i$ - ratio of current backlog of timber contracts in $\mathrm{m}^{3}$ to maximum backlog of timber contracts in $\mathrm{m}_{3}$

- CYCLE: estimated cycle time for harvested timber

- LNB: natural log of the number of bidders.

- Category 2: indicator variable that equals one for any bidder that only participates in Category 2 auctions

- Distance: The distance in $\mathrm{km}$ from the bidder's city of residence to the center of the auctioned plot.

Table 2 provides parameter estimates for equations (1) and (1') estimated for different subsets of the 5,524 observations. We should note that the number of bidders in SBFEP auctions is likely an endogenous measure. Taking the number of bidders as an exogenous measure is thus somewhat problematic. However, we are unaware of any method to solve for endogenous entry using an instrumental variables approach since $\mathrm{n}$ affects bids directly through the level of expected competition in the primary auction market and the expected division of surplus on the secondary market.

Empirical results presented in Table 2 suggest an important difference in the behavior of mills versus loggers that are consistent with resale possibilities for the former set of bidders. First, the indicator variable for Category 2 bidders (mills) in both columns 1 and 2 suggests that such agents submit bids that are ceteris paribus $\$ 1.47$ - $\$ 1.68$ greater than those submitted by a registered logger in a Category 1 auction with this difference statistically significant at the $\mathrm{p}<$ 
0.05 level. Second, measured at the sample means and using parameter estimates from Columns 4 and 5, the estimated marginal effect of adding an additional bidder in a Category 2 auction is $\$ 2.11$ (4.4\% increase in the predicted bid) as opposed to $\$ 0.91(2.01 \%$ increase in the predicted bid) for a Category 1 auction.

Equilibrium bidding strategies in auctions with resale are conditioned upon information related to other bidders in the market that is absent in the strategy of a firm bidding in a market without resale. Hence, we would expect greater competition in the former case when the secondary market institution is an OA continuation game of complete information (or a similar analog), as we assume for the Category 2 mills. This finding is consonant with the predictions and analysis employed by Haile (2001). Combined with other results in Table 2 (e.g., the estimated increase in predicted bids for Category 2 auctions), we take the evidence to suggest that resale opportunities influence bidding in the direction that theory would predict.

\section{Experimental Design and Results}

Given the vast number of caveats and assumptions that we must make to our reduced form approach, however, we are skeptical that observed differences across bidder types can be attributed solely to resale and the possibility of secondary market exchange. ${ }^{8}$ This skepticism induces us to focus more exclusively on studying artificial markets that differ only in whether a secondary market is available. In doing so, we present a first experiment that examines whether the resale market by itself can lead to predicted consequences.

\section{Experimental Design}

A total of 90 subjects participated in our laboratory experiment, which was conducted during the Fall 2003 and Spring 2004 semesters at the University of Maryland in College Park. Each session consisted of two experimental parts: a first-price auction market with or without

\footnotetext{
${ }^{8}$ Yet we should note that we find evidence in line with Haile's (2001) findings.
} 
resale opportunity and the Holt and Laury (2002) experimental procedure to elicit the risk preference of each participant. Each part of the laboratory experiment is described below.

\section{Part I: The Auction Market}

Each subject's experience typically followed four steps: (1) consideration of an invitation to participate in an experiment, (2) learning the auction rules, (3) actual market participation, and (4) conclusion of the experiment and completion of the Holt and Laury (2002) risk-aversion experiment. In Step 1, undergraduate students from the University of Maryland were recruited using e-mail solicitations and flyers hung in academic buildings across the campus. Once the prerequisite number of subjects had responded, a second e-mail was sent to each participant inviting them to participate in an experimental session to be held at a given date/time. After subjects were seated in a room, in Step 2 a monitor thoroughly explained the experimental instructions and auction rules (included in Appendices A and B).

Before proceeding, a few key aspects of the experimental design should be highlighted. First, all bidders were informed that earnings from the auction experiment would be added to earnings from a second, unrelated experiment to determine total earnings for the session. Second, individuals were informed that they would be bidders in the experiment. In each of the 12 rounds ( 2 practice and 10 that count towards earnings), they would be given a bidder's card that contained a number, known only to that bidder, representing a signal of the value of one unit of the fictitious commodity. Importantly, all agents were informed that this information was strictly private and that both signals and use values would change each round. They were also informed about the number of other bidders in the market (4), that they would bid against the same four bidders for all ten rounds, and that agents may have different signals (use values). 
Third, the monitor explained how signals were determined in each market period and how these signals related to the agent's final reservation (use) value. Subjects were informed that in each period, they would receive a signal from the interval $[\$ 0, \$ 50]$. These signals were determined by adding a random integer generated from a uniform distribution on the interval [$\$ 10, \$ 10]$ to the agent's final use value which was itself an integer value randomly drawn on the uniform interval $[\$ 10, \$ 40]$. Several examples illustrated the relationship between a given use value and the range of signals that the bidder could receive in the first stage, and vice versa.

Fourth, the monitor explained how earnings were determined. In the baseline, no resale treatment, the highest bidder earns the difference between their end use value and their bid. All other bidders earn zero. In the resale treatment with OA continuation game, the bidder who submits the highest bid earns the difference between the highest use value of all bidders and the winning bid. All other bidders earn zero. In the resale treatment with EA continuation game, the bidder who submits the highest bid receives the maximum of her use value and the second highest use value of all participants minus her winning bid. The bidder who does not submit the high bid but has the highest use value receives the difference between this value and the second highest use value of all other participants. All other bidders earn zero for the round. Total earnings for each treatment are computed by summing the earnings across the 10 periods.

In the resale treatment with OA continuation game, it was publicly announced that following the completion of each round, ownership of the good would be sold to the agent with the highest use value in the group at a price equal to her value. In the resale treatment with EA continuation game, it was publicly announced that following the completion of each round, ownership of the good would be sold to the agent with the highest use value in the group at a 
price equal to the second highest use value of all agents in the group. ${ }^{9}$ In the baseline no-resale treatment, several examples were provided that illustrated the irrationality of bidding more than $\$ 10$ above a received signal. In the resale treatments several examples were provided that illustrated the workings of the resale market and how prices for resale exchange and earnings for each bidder would be determined. ${ }^{10}$ Fifth, individuals participated in 2 practice rounds of bidding to gain experience with the auction market and rules.

In Step 3, subjects participated in the market. Each market consisted of 10 rounds of bidding that lasted about 3 minutes each. After each 3-minute period, a monitor privately gathered each subject's bidder card and gave the bidder a second card containing the subject's final use value that was within $[-\$ 10, \$ 10]$ of the original signal. Once all bidder cards were collected, a monitor publicly announced all bids and awarded the good to the highest bidder. Final use values were publicly announced and, in the resale treatment, ownership of the commodity transferred to the agent with highest use value.

It should be noted that throughout each session careful attention was given to prohibit communications between bidders that could induce collusive outcomes. Step 4 concluded the

\footnotetext{
${ }^{9}$ Two important features of our experimental design that we should highlight include: i) our choice to limit participation on the secondary market to bidders from the primary auction market and ii) our decision to execute trades on the secondary market at the theoretical benchmarks for both the OA and EA game of complete information. We elected to limit participation on the secondary market and execute trades at the theoretical benchmarks to maintain consistency with our conceptual model. As a first experimental test, it is apropos to focus the analysis on first-stage bidding strategies rather than secondary market exchange. Allowing the endogenous determination of prices on the secondary market would surely have an influence on bidding strategies, as it is likely that rents would not be divided on the secondary market as predicated by theory. Anticipating this, bidders would adjust first-stage bidding strategies. We hope that future work analyzes behavior in markets where prices are endogenously determined on the secondary market and new participants are allowed to enter the second-stage continuation game.

${ }^{10}$ An important consideration in designing our auction markets was the issue of bankruptcy and bidder behavior. Theoretically, bankruptcy was not an issue if subjects played the risk-neutral Nash equilibrium. However, equilibrium payouts in a number of the periods were low enough to raise concern if subjects determined bids with a degree of error. For reasons outlined in Hansen and Lott (1991), we decided to employ an unlimited liability rule and allow subjects to have negative earnings for Part I of the experiment.
} 
experiment - after subjects completed the Holt and Laury (2002) experiment (described in Part II of this section), they were paid their earnings in private.

This simple procedure was followed in each of three treatments, which are summarized in Table 3. Table 3 can be read as follows: row 1, column 2 of Table 3 contains treatment NR, denoting a no-resale auction market with 5 bidders, who each have unit demand for the good. Table 4 presents buyer induced values and signals for each market period. All signals were drawn and assigned using the following procedure. We first drew 50 integer numbers on the uniform distribution between [\$10, \$40] using Excel's random number generator. We added an integer drawn on the uniform distribution $[-\$ 10, \$ 10]$ to this number to obtain signal values. These values were then assigned so that unbeknownst to bidders, in each session (i) every bidder received the highest signal twice, (ii) each bidder received the highest use value but a lower ordered signal, and (iii) resale trade was potentially profitable in half of the periods.

\section{Part II: The Holt-Laury Risk Experiment}

Upon completion of Part 1 of the session, instructions and a decision sheet were handed out for the second part of the experiment. This second part was designed to elicit subjects' risk preferences. In this part of the session, the low-payoff treatment of Holt and Laury (2002) was used (see Appendix B for instructions). ${ }^{11}$ The treatment is based on ten choices between paired lotteries. The payoff possibilities for Option A, $\$ 2.00$ or $\$ 1.60$, are much less variable than those for Option B, $\$ 3.85$ or $\$ 0.10$, which was considered the risky option. The odds of winning the higher payoff for each of the options increased with each decision, and the paired choices are

\footnotetext{
${ }^{11}$ We elected to use the low-payoff treatment of the Holt and Laury (2002) experiment to measure risk preference since the domain of earnings because this treatment [\$0.10 to $\$ 3.85]$ approximates the equilibrium domain of per period earnings for our auction markets. We also collected data for a higher-payoff treatment of the Holt and Laury (2002) experiment, where the domain of earnings [\$0.40 to $\$ 15.40]$ approximates the equilibrium domain of earnings at the session level in our auction markets. In what follows, we report only the empirical results for risk preference based upon individual response to the low-payoff Holt and Laury (2002) design. However, all tests and results are robust to the use of response to the higher-payoff experiment.
} 
designed to determine degrees of risk aversion. Holt and Laury (p. 1649) provide a table that will be used to categorize subjects' CARA risk preference levels based on their ten decision choices.

After the instructions were read and questions were answered, the subjects were asked to complete their decision sheets by choosing either A or B for each of the ten decisions. The subjects were instructed that one of the decisions would be randomly selected ex post and used to determine their payoffs. Part of a deck of cards was used to determine payoffs, cards 2-10 and the Ace to represent "1". After each subject completed his or her decision sheet, a monitor would approach the desk and randomly draw a card twice, once to select which of the ten decisions to use, and a second time to determine what the payoff was for the option chosen, A or B, for the particular decision selected. After the first card was selected, it was placed back in the pile, the deck was reshuffled, and the second card was drawn. For example, if the first draw was an Ace, then the first decision choice would be used. Suppose the subject selected A in the first row. The second draw would then be made. If the Ace was drawn, the subject would win $\$ 2.00$. If a card numbered 2-10 was drawn, the subject would win $\$ 1.60$. The subjects were aware that each decision had an equal chance of being selected.

After all the subjects' payoffs were determined, they combined their payoff from Part 1 with that of Part 2 to compute their final earnings. The final payoffs were then verified against records maintained by a monitor, and subjects were paid privately in cash for their earnings. Each of the sessions lasted approximately 75 minutes and average earnings were roughly $\$ 13$.

Theoretical predictions for the laboratory auction markets

Figure 1 provides theoretical predictions for risk-neutral bidders in our experimental markets conditioned on the signal. Across all but the lowest level of the signal space $(\$ 0.00)$, 
bidders in markets with resale opportunities represented by an OA continuation game are predicted to submit bids that are higher than those submitted by an equivalent bidder in a market without resale options. These differences range from mere pennies for signals less than $\$ 5.00$ to a maximum of about $\$ 3.40$ for bids submitted in the signal range around $\$ 23 .^{12}$ For signal ranges above $\$ 40.00$ or below $\$ 20$, the predicted differences in bids between the no-resale and resale treatments are less than $\$ 2.75$.

In resale treatments represented by an EA continuation game, risk-neutral bidders are predicted to submit bids that are on average higher than those submitted by an equivalent bidder in a market without resale at ranges of our signal space of less than $\$ 27.00$. For signals larger than $\$ 27.00$, risk-neutral bidders in our resale treatment with EA continuation game are predicted to submit bids that are on average less than those submitted by an equivalent bidder in the noresale treatment. These differences range from a maximum of $\$ 0.70$ at a signal of approximately $\$ 20.00$ to a minimum of $\$-0.56$ at a signal of approximately $\$ 46.00$.

Experimental Results

Table 5 provides summary statistics for the experimental data. Entries in Table 5 are at the period level and include average bid level and its standard deviation, the average winning bid and its standard deviation, and the average resale price. Table 5 can be read as follows: on average, in period 1 of the No Resale treatment, subjects submit a bid of $\$ 20.84$ (standard deviation $=9.32)$ and the average winning bid is $\$ 30.77($ standard deviation $=3.17)$. Perusal of the data summary in Table 5 leads to our first two results:

Result 1: Bids in a first-price auction followed by resale exchange in an OA continuation game are greater than those submitted in equivalent markets without resale.

\footnotetext{
${ }^{12}$ The optimal bid functions were derived numerically. The algorithm is available upon request.
} 
Result 2: Bids in a first-price auction followed by resale exchange in an OA continuation game are greater than those submitted in equivalent markets with an EA continuation game.

These results can be seen most directly by examining both per period average and winning bids across our three laboratory treatments. Across each of the ten market periods, both average and winning bids in the resale treatment with OA continuation game are greater than bids in both the baseline (no resale) treatment and the resale treatment with EA continuation game.

Our last piece of evidence to support Results 1 and 2 comes from a random effects bid equation of the following form:

$$
B_{\text {it }}=Z_{\mathrm{it}} \beta+\varepsilon_{\mathrm{it}},
$$

where $B_{\mathrm{it}}$ is the bid of the $i$ th buyer in period $t$. Vector $Z_{\mathrm{it}}$ includes treatment dummy variables, the induced signal received by the agent and to maintain consistency with our theory the square of the signal. Session fixed effects are also included, and we model $\varepsilon_{i t}=\alpha_{i}+u_{i t} ; \mathrm{E}\left[\alpha_{i}\right]=0$, $\mathrm{E}\left[\alpha_{i}^{2}\right]=\sigma_{\alpha}^{2}, \mathrm{E}\left[\alpha_{i} \alpha_{j}\right]=0$ for $i \neq j ; \alpha_{i}$ and $u_{i t}$ are orthogonal for all $i$ and $t$. The random effects $\alpha_{i}$ capture important heterogeneity across agents that would be left uncontrolled in a standard crosssectional model.

Column A in Table 6 presents regression results which provide support for our first two results. For example, parameter estimates in column A suggest that average bids in the OA treatment are $\$ 5.85$ higher than average bids in the baseline treatment (the omitted categorical variable) with this difference statistically significant at the $\mathrm{p}<.05$ level. Furthermore, using a Chow test of coefficient equality, we find that OA bids are larger than EA bids at the $p<.05$ level. As column B of Table 6 shows, these differences are robust across empirical specifications that allow the treatment effects to differ over lower (higher) ranges of the signal space - i.e., over signals less than (greater than) $\$ 26.00$. 
Empirical results in Table 5 suggest that baseline bids and EA treatment bids are isomorphic. Yet, when bids are analyzed over ranges of signals less than (greater than) \$26, where our theory hypothecates that bids from the EA treatment are greater than (less than) those submitted in the baseline treatment, we find evidence consonant with the theory. Over lower ranges of the signal space, bids from the EA treatment are $\$ 2.73$ larger than those from the baseline treatment, a statistically significant difference at the $p<0.05$ level. ${ }^{13}$ Over higher ranges of the signal space, bids from the EA treatment average \$2.07 less than those from the baseline treatment, with these differences statistically significant at the $p<0.05$ level. These data patterns lead to the next result:

Result 3: Over lower (higher) signal ranges, bidders in a first-price auction followed by an EA continuation game submit bids that are higher (lower) than those submitted by agents in an equivalent baseline market without resale opportunity.

Empirical estimates in Table 6 provide regression results which highlight this result. For example, parameter estimates from Column A suggest that over the entire signal domain, there is little discernable difference between bids - the estimate on the indicator for our EA treatment is not significant at any meaningful level. However, when we examine behavior over different ranges of the signal space, as in Column B, we observe significant differences across our EA and baseline treatments. Over lower ranges of the signal space, bids from the EA treatment are approximately $\$ 2.38$ greater than the bids from our baseline auction markets. And, at a higher range of the signal space, the bids from the EA treatment are approximately $\$ 2.08$ less than the average bids from our baseline market. Both of these differences are statistically significant at the $\mathrm{p}<0.05$ level using a Chow test of coefficient equality.

Departures from Risk Neutral Predictions: The Role of Risk Aversion

\footnotetext{
${ }^{13}$ Statistical significance is evaluated using the Mann-Whitney test of significance evaluated at the session level. These are demanding exercises since test statistics are based upon a comparison of average bid levels for signals less than (greater than) \$26 in each of our six EA sessions versus comparable averages from our six baseline sessions.
} 
Having found support that bidders respond to changes in the option value conveyed by resale, we now examine more closely the predictions of the theory. Figure 2 provides an illustration of average bids (by signal) in our baseline no-resale market relative to the theoretical predictions for risk-neutral equilibrium bids. As can be seen from the figure, risk-neutral point predictions do not fit the data well. Over lower ranges of the signal space, realized bids are less than the risk-neutral theoretical predictions while over higher ranges, realized bids are greater than risk-neutral theoretical benchmarks. Similar patterns, albeit less pronounced, arise in Figures 3 and 4 which plot average bids (by signal) for both the OA and EA treatments

This raises two important questions for evaluating bidder behavior in auction markets. First, to what extent can such behavior be explained by the underlying risk preference of bidders? There has been considerable debate over the ability of traditional theory to account for observed patterns of bidding in experimental first-price, private value auctions. ${ }^{14}$ A number of studies have attempted to recover and infer the level of risk-aversion that rationalizes the observed bids of subjects in controlled laboratory environments (i.e., Cox and Oaxaca (1995); Cox et al. (1985); Goeree et al. (2002)). In this study, we take a different route and directly elicit individual measures of risk posture and use this information as a control in estimating observed bidding behavior. As such, we are able to correlate differences in observed bids with variations in risk preference across agents. ${ }^{15}$

Second, to what extent is the coherence of hypothesis tests affected by the specification of underlying bidder risk preference? Lange et al. (2004) develop a theoretical model which highlights that the effect of resale on bidding strategies is attenuated by risk aversion.

\footnotetext{
${ }_{15}^{14}$ See Kagel (1995) for an overview of this debate.

${ }^{15}$ Of course, unlike our experimental treatments risk posture should not be regarded as something we can exogenously impose on subjects. Thus, we exercise caution when interpreting the data in that risk posture could be systematically related to individual-specific unobservables that cause the data patterns discussed below.
} 
Incorrectly assuming the risk-preference of agents can thus impact the magnitude of estimated resale effects.

To evaluate the impact of risk preference on observed bids, we augment equation (5) by including an interaction of an individual's risk preference with his/her signal, the signal squared, and the treatment dummies. ${ }^{16}$ Empirical estimates from this model are contained in column $\mathrm{C}$ of Table 6. We obtain the following insight from these results:

Result 4: Over all but the lowest range of signals, risk-averse agents submit bids that are greater than their risk-neutral counterparts, with this difference increasing in the level of individual risk-aversion.

Support for Result 4 can be garnered by examining the marginal effect of our risk proxy on realized bids. For example, in Column $\mathrm{C}$ of Table 6 the estimated marginal effect of risk preference on realized bids in the baseline treatment is given by $[-2.94+0.20 *$ Signal $0.002 *$ Signal $^{2}$ ]. This marginal effect is strictly positive for any signal greater than $\$ 15$. For any signal greater than $\$ 15$ in the baseline treatment, the bid of a risk-averse agent should exceed that of a risk neutral counterpart receiving the same induced signal. Similar patterns arise for both the EA and OA treatments. In the EA (OA) treatment, risk-averse agents submit bids that are greater than a risk-neutral counterpart for any signal above $\$ 19(\$ 21)$. Our data thus suggest a direct correlation between over-bidding and individual risk preference.

Having found evidence that risk-aversion is correlated with observed patterns of bidding in our auctions, we now turn to examining the influence of individual risk preference on our estimated treatment effects. Our theoretical model suggests that increased risk aversion serves to

\footnotetext{
${ }^{16}$ To proxy each agent's risk posture, we use the number of safe choices "Lottery A" selected by the agent in the Holt-Laury experimental design. An increase in the number of safe choices represents an increase in the individual's implied risk posture. For example, an agent who selects option A for the first four choice occasions is considered risk neutral whereas an agent who selects option A for the first six choice options has CARA risk preference of approximately 0.5 . Figure 5 provides the frequency distribution of the implied CARA preference (by treatment) for the 90 subjects in our experiment auctions.
} 
attenuate the effect of resale. Empirical support for this conjecture follows from a comparison of estimated treatment effects in model specifications that control for individual risk preference (Columns $\mathrm{C}$ and $\mathrm{D}$ ) with those that do not condition behavior on risk preference (Column A). For example, the estimated treatment effect on the OA dummy variable is at least $\$ 7.21$ greater in models that explicitly control for individual risk preference with this difference statistically significant at the $\mathrm{p}<0.05$ level. Hence failing to account for individual risk posture, will tend to underestimate the impact of resale opportunities on observed bids.

The above discussion treats risk posture as if it is homogenous across agents. However, subjects in our experiment and in many other settings demonstrate heterogeneities in risk posture. An important question is thus how such variations affect the observed behavior of agents. To address this issue, we calculate the average risk preference for subjects in each session and augment equation (5) by including an interaction of the average risk preference with induced signal and an interaction of these values with a measure of individual risk preference. Empirical estimates from this model are contained in column D in Table 6. We obtain the following insight from these results:

Result 5: Bids are decreasing (increasing) in the average risk posture of competitors over lower (higher) ranges of signals.

Although we are unaware of any theoretical model that examines heterogeneous risk posture in auctions with resale, Result 5 is consistent with intuition. Over lower ranges of signals, bids of opponents are decreasing in their level of risk-aversion. Responding to this, an individual can also decrease his bids. Over higher signal ranges, however, an increased riskaversion of opponents leads to increased bids. Faced with such a more competitive environment, an individual might react by also increasing his bids. 
Support for Result 5 is gained by examining the marginal effect of average risk preference at the session level (Mean Risk) on realized bids. For example, in column D of Table 6 , the estimated marginal effect of mean risk on realized bids is given by:

$$
\frac{\partial b i d_{N R}}{\partial M e a n_{-} \text {Risk }}=-1.61+0.12 \cdot \text { Signal }-0.01 \cdot \text { Ind_Risk } \cdot \text { Signal }
$$

which is positive for any induced signal greater than twenty for a risk-neutral agent - i.e., an agent who selects Option A in the Holt-Laury experiment for the first four choice occasions. In fact, for any agent who selects Option A fewer than nine times, this expression is positive over some range of the induced signal space.

Departures from Theoretical Benchmarks: The Role of Speculation

Having explored the role of risk posture on departures from theoretical benchmarks, we now examine whether resale possibilities introduce speculative motives that could explain observed over-bidding. Across all three of our experimental treatments, only those bidders receiving the highest signal in a particular round should win an auction. Table 7 explores this conjecture by summarizing the frequency with which the winning bid is submitted by those who received signal of different rank order. As noted in Table 6, the bidder who receives the highest signal in our baseline treatment wins 80 percent of all auctions. In contrast, such bidder wins only 51.7 percent (43.3 percent) of the auctions in our corresponding OA (EA) treatment. This leads to a final result:

Result 6: Resale introduces speculative motives for bidding. Bidders receiving the highest signal (lower ordered signals) are less (more) likely to win auctions in treatments with resale.

Statistical support for Result 6 is contained in Table 8 which examines the likelihood with which bidders that receive the highest (Column A) or lower ordered (Column B) signals win our 
auctions. As noted in Column A, the bidder with the highest signal is significantly less likely to win an auction when we introduce resale possibilities organized by either an OA or EA continuation game of complete information. In contrast, bidders that receives lower ordered signals are significantly more likely to win an auction in these treatments than are counterparts in our baseline, no resale treatment.

\section{Conclusions}

Auctions are ubiquitous. Yet whether and to what extent the introduction of secondary resale markets influences bidding behavior when private values are uncertain remains largely unknown. We begin by exploring a novel data set that provides insights into the importance of the resale effect. Reduced-form empirical estimates suggest that bidding patterns are consistent with theoretical predictions. Yet, akin to many empirical exercises with naturally-occurring data, the strength of inference is attenuated when one considers the set of maintained assumptions needed to generate confident conclusions from these data.

Our approach to this problem is to make use of a laboratory experiment. Such an effort gives up much of the realism associated with field data, but it permits us to investigate whether the resale market by itself can lead to such predicted consequences. We find that extant theory has considerable predictive power, but the accuracy of the theory is enhanced if we control for individual risk preferences. Besides their obvious importance normatively, these results have practical policy significance as well. For example, a necessary condition to lift the countervailing duty and anti-dumping ruling against Canadian softwood lumber exporters (who export to the U.S.) is that their auction markets be robust and not influenced unduly by collusion. Without a proper understanding of the resale opportunities of the various bidders, the modeler 
may very well earmark bidding disparities among certain bidder types as evidence of collusion when it is in fact due merely to secondary market considerations. 


\section{References}

Athey, Susan, Jonathan Levin, and Enrique Seira, "Comparing Open and Sealed Bid Auctions: Theory and Evidence from Timber Auctions," working paper Stanford University, 2004.

Bikhchandani, Sushil and Chi-fu Huang, "Auctions with Resale Markets: An Exploratory Model of Treasury Markets," The Review of Financial Studies (1989), 2(3), pp. 311-339.

Cox, James and Ronald Oaxaca, "Inducing Risk-Neutral Preferences: Further Analysis of the Data," Journal of Risk and Uncertainty (1995), 11(1): pp. 65-79.

Cox, James, Vernon Smith and James Walker, "Experimental Development of Sealed-Bid Auction Theory: Calibrating Controls for Risk Aversion," American Economic Review (1985), 72(2): pp. 160-165.

Garratt, Rod and Thomas Troger, "Speculation in Standard Auctions with Resale," Econometrica (2006), 74: pp. 753-769.

Georganas, Sotiris, "English Auctions with Resale: An Experimental Study," working paper University of Bonn, 2009.

Georganas, Sotiris and John Kagel, "Asymmetric Auctions with Resale: An Experimental Study," working paper University of Bonn, 2009.

Goeree, Jacob, Charles Holt, and Thomas Palfrey, "Quantal Response Equilibrium and Overbidding in Private-Value Auctions," Journal of Economic Theory (2002), 104(1): pp. 247-272.

Goeree, Jacob and Theo Offerman, "Competitive Bidding in Auctions with Private and Common Values," The Economic Journal (2003), 113(July): pp. 598-613.

Guerre, Emmanuel, Isabelle Perrigne and Quang Vuong, "Optimal Nonparametric Estimation of First-Price Auctions," Econometrica (2000), 68(3): pp. 525-574.

Gupta, Madhurima and Bernard Lebrun, "First Price Auctions with Resale," Economics Letters (1999), 64(3-4): pp. 181-185.

Haile, Philip, "Partial Pooling at the Reserve Price in Auctions with Resale Opportunities," Games and Economic Behavior (2000), 33: pp. 231-248.

Haile, Philip, "Auctions with Resale Markets: An Application to U.S. Forest Service Timber Auctions," American Economic Review (2001), 99: pp. 399-427.

Haile, Philip, "Auctions with Private Uncertainty and Resale Opportunities," Journal of Economic Theory (2003), 108(1): pp. 72-110.

Hansen, Robert and John Lott, "The Winner's Curse and Public Information in Common Value Auctions: Comment," American Economic Review (1991), 81(1): pp. 347-361.

Holt, Charles and Susan Laury, "Risk Aversion and Incentive Effects". American Economic Review, (2002), 92: 1644-1655.

Jehiel, Phillippe and Benny Moldovanu, "Efficient Design with Interdependent Valuations," Econometrica (2001), 69(5): pp. 1237-1259.

Kagel, John, "Auctions: A Survey of Experimental Research," in J.H. Kagel and A.E. Roth (eds.), The Handbook of Experimental Economics, Princeton: Princeton University Press (1995).

Klemperer, Paul, "Auction Theory: A Guide to the Literature," Journal of Economic Surveys, (1999), 13(3): pp. 227-286. 
Laffont, Jean-Jacques, Herve Ossard and Quang Vuong, "Econometrics of First-Price Auctions," Econometrica (1995), 63(4): pp. 953-980.

Lange, Andreas, John A. List and Michael K. Price, "Auctions with Resale when Private Values are Uncertain: Theory and Empirical Evidence,” NBER Working Paper 10639, (2004).

Pesendorfer, Wolfgang and Jeroen Swinkels, "Efficiency and Information Aggregation in Auctions," American Economic Review (2000), 90(3): pp. 499-525.

Porter, Robert and Douglas Zona "Detection of Bid Rigging in Procurement Auctions," Journal of Political Economy (1993), 101: pp. 518-538.

Porter, Robert H. and Douglas Zona, "Ohio School Milk Markets: An Analysis of Bidding," Rand Journal of Economics (1999) 30: 263-288.

Schwarz, Michael and Konstantin Sonin, "The Variable Value Environment: Auctions and Actions" (May 2001). Harvard Institute of Economic Research Paper No. 1918. 
Table 1: Summary Statistics - SBFEP Auction Data

\begin{tabular}{|l|c|c|c|}
\hline & All Data & Loggers Only & Mills Only \\
\hline Deflated Bid & 45.69 & 45.51 & 48.26 \\
& $(17.39)$ & $(17.53)$ & $(14.95)$ \\
\hline Upset & 33.45 & 33.22 & 36.60 \\
& $(14.97)$ & $(15.04)$ & $(13.67)$ \\
\hline LSPI & 115.23 & 114.91 & 119.75 \\
\hline DC & 1.48 & 1.48 & 1.47 \\
\hline VPH_1000 & 0.27 & 0.27 & 0.28 \\
\hline NCV_1000 & 8.99 & 9.03 & 8.45 \\
\hline Slope & 16.10 & 15.78 & 20.58 \\
\hline LNVPT & -0.79 & -0.80 & -0.71 \\
\hline Bwdn & 0.02 & 0.02 & 0.01 \\
\hline Burn & 0.01 & 0.01 & 0.02 \\
\hline Cy & 0.07 & 0.06 & 0.10 \\
\hline Horse & 0.07 & 0.07 & 0.01 \\
\hline Cycle & 3.86 & 3.89 & 3.37 \\
\hline LNB & 1.68 & 1.71 & 1.30 \\
& $(0.52)$ & $(0.51)$ & $0.41)$ \\
\hline Util2 & 0.24 & 0.24 & 0.20 \\
& $(0.34)$ & $(0.34)$ & 163.76 \\
\hline Distance in km from & 150.22 & 149.67 & \\
Plot & & & . \\
\hline
\end{tabular}

Note: Cell entries are mean values for the various covariates included in our regression models. Associated standard deviations are in parentheses. 
Table 2: Random Effects Regression Estimates: Interior SBFEP Auction Data

\begin{tabular}{|c|c|c|c|c|c|}
\hline & $\begin{array}{l}\text { Model (1) } \\
\text { Only Bid in } \\
\text { Cat } 1 \text { or } 2\end{array}$ & $\begin{array}{l}\text { Model (1) } \\
\text { Only Bid in } \\
\text { Cat } 1 \text { or } 2\end{array}$ & $\begin{array}{l}\text { Model (1') } \\
\text { Pooled Data }\end{array}$ & $\begin{array}{c}\text { Model (1') } \\
\text { Loggers Only }\end{array}$ & $\begin{array}{l}\text { Model (3') } \\
\text { Mills Only }\end{array}$ \\
\hline Constant & $\begin{array}{c}4.40^{* *} \\
(1.15) \\
\end{array}$ & $\begin{array}{c}6.84 * * \\
(1.33) \\
\end{array}$ & $\begin{array}{l}5.65^{* *} \\
(1.17) \\
\end{array}$ & $\begin{array}{l}5.90 * * \\
(1.19)\end{array}$ & $\begin{array}{c}1.55 \\
(5.31)\end{array}$ \\
\hline Upset & $\begin{array}{l}0.87^{* *} \\
(0.01)\end{array}$ & $\begin{array}{l}0.85^{* *} \\
(0.01)\end{array}$ & $\begin{array}{l}0.82 * * \\
(0.01)\end{array}$ & $\begin{array}{l}0.82 * * \\
(0.14)\end{array}$ & $\begin{array}{l}0.74 * * \\
(0.05)\end{array}$ \\
\hline LSPI & $\begin{array}{l}0.04 * * \\
(0.01)\end{array}$ & $\begin{array}{l}0.05^{* *} \\
(0.009)\end{array}$ & $\begin{array}{l}0.06^{* *} \\
(0.01)\end{array}$ & $\begin{array}{l}0.06 * * \\
(0.01)\end{array}$ & $\begin{array}{l}0.11^{* *} \\
(0.03)\end{array}$ \\
\hline $\mathrm{DC}$ & $\begin{array}{c}-0.13^{* *} \\
(0.05)\end{array}$ & $\begin{array}{c}-0.23 * * \\
(0.06)\end{array}$ & $\begin{array}{c}-0.18^{* *} \\
(0.05)\end{array}$ & $\begin{array}{c}-0.26^{* *} \\
(0.05)\end{array}$ & $\begin{array}{l}0.97 * * \\
(0.20)\end{array}$ \\
\hline VPH_1000 & $\begin{array}{c}4.07 * * \\
(1.07) \\
\end{array}$ & $\begin{array}{l}2.52^{*} \\
(1.13) \\
\end{array}$ & $\begin{array}{l}5.20 * * \\
(1.07)\end{array}$ & $\begin{array}{l}5.02 * * \\
(1.08) \\
\end{array}$ & $\begin{array}{c}8.13 \\
(5.32) \\
\end{array}$ \\
\hline NCV_1000 & $\begin{array}{l}-0.02 \\
(0.02)\end{array}$ & $\begin{array}{l}-0.05^{*} \\
(0.02) \\
\end{array}$ & $\begin{array}{l}-0.01 \\
(0.02)\end{array}$ & $\begin{array}{l}-0.01 \\
(0.02)\end{array}$ & $\begin{array}{l}-0.06 \\
(0.06) \\
\end{array}$ \\
\hline Slope & $\begin{array}{l}0.06 * * \\
(0.02)\end{array}$ & $\begin{array}{l}0.04^{*} \\
(0.02)\end{array}$ & $\begin{array}{l}0.03 * * \\
(0.015)\end{array}$ & $\begin{array}{l}0.04 * * \\
(0.02)\end{array}$ & $\begin{array}{l}-0.06 \\
(0.06)\end{array}$ \\
\hline LNVPT & $\begin{array}{l}1.52 * * \\
(0.30)\end{array}$ & $\begin{array}{l}1.83 * * \\
(0.33) \\
\end{array}$ & $\begin{array}{l}1.85^{* *} \\
(0.30)\end{array}$ & $\begin{array}{l}1.86^{* *} \\
(0.31)\end{array}$ & $\begin{array}{c}0.22 \\
(1.19) \\
\end{array}$ \\
\hline Bwdn & $\begin{array}{c}-0.79 \\
(1.16) \\
\end{array}$ & $\begin{array}{c}0.66 \\
(1.37) \\
\end{array}$ & $\begin{array}{l}-1.93^{*} \\
(1.16) \\
\end{array}$ & $\begin{array}{l}-1.49 \\
(1.17) \\
\end{array}$ & $\begin{array}{r}-10.91 \\
(6.93) \\
\end{array}$ \\
\hline Burn & $\begin{array}{l}-3.22 * \\
(1.36)\end{array}$ & $\begin{array}{l}-0.65 \\
(1.15)\end{array}$ & $\begin{array}{c}-3.86^{* *} \\
(1.33) \\
\end{array}$ & $\begin{array}{c}-3.19^{* *} \\
(1.40) \\
\end{array}$ & $\begin{array}{c}-11.50^{* *} \\
(4.23) \\
\end{array}$ \\
\hline $\mathrm{Cy}$ & $\begin{array}{c}-2.88^{* *} \\
(0.74)\end{array}$ & $\begin{array}{c}-2.55^{* *} \\
(0.83)\end{array}$ & $\begin{array}{c}-3.20^{* *} \\
(0.73)\end{array}$ & $\begin{array}{c}-3.22 * * \\
(0.78)\end{array}$ & $\begin{array}{l}-1.03 \\
(2.37) \\
\end{array}$ \\
\hline Horse & $\begin{array}{c}-2.49 * * \\
(0.66)\end{array}$ & $\begin{array}{c}-3.20 * * \\
(0.77)\end{array}$ & $\begin{array}{c}-3.93 * * \\
(0.65)\end{array}$ & $\begin{array}{c}-3.67 * * \\
(0.66)\end{array}$ & $\begin{array}{l}-10.81 \\
(7.15)\end{array}$ \\
\hline Cycle & $\begin{array}{c}-0.41^{* *} \\
(0.08) \\
\end{array}$ & $\begin{array}{c}-0.41^{* *} \\
(0.09) \\
\end{array}$ & $\begin{array}{c}-0.53^{* *} \\
(0.08) \\
\end{array}$ & $\begin{array}{c}-0.53 * * \\
(0.08)\end{array}$ & $\begin{array}{l}-0.33 \\
(0.43)\end{array}$ \\
\hline LNB & $\begin{array}{l}5.63 * * \\
(0.24)\end{array}$ & $\begin{array}{l}5.54 * * \\
(0.26)\end{array}$ & $\begin{array}{l}5.22 * * \\
(0.24)\end{array}$ & $\begin{array}{l}5.18^{* *} \\
(0.25)\end{array}$ & $\begin{array}{l}7.81 * * \\
(1.29) \\
\end{array}$ \\
\hline Util2 & $\begin{array}{c}-2.70^{* *} \\
(0.36) \\
\end{array}$ & $\begin{array}{c}-2.25^{* *} \\
(0.40) \\
\end{array}$ & $\begin{array}{c}-2.69^{* *} \\
(0.36) \\
\end{array}$ & $\begin{array}{c}-2.62 * * \\
(0.36) \\
\end{array}$ & $\begin{array}{c}-2.86^{* *} \\
(1.49) \\
\end{array}$ \\
\hline Category 2 & $\begin{array}{l}1.68 * * \\
(0.68)\end{array}$ & $\begin{array}{l}1.47^{* *} \\
(0.49)\end{array}$ & & & \\
\hline $\begin{array}{l}\text { Distance in km } \\
\text { from plot }\end{array}$ & & $\begin{array}{c}-0.005^{* *} \\
(0.001) \\
\end{array}$ & & & \\
\hline $\begin{array}{l}\text { Buyer Random } \\
\text { Effects }\end{array}$ & Yes & Yes & Yes & Yes & Yes \\
\hline \# of Firms & 1245 & 683 & 1245 & 1105 & 140 \\
\hline \# of Obs & 5524 & 4325 & 5524 & 5148 & 376 \\
\hline Log Likelihood & -20537.2 & -20423.5 & -19632.7 & -18225.7 & -1371.3 \\
\hline Predicted Bid & & & $\begin{array}{c}45.69 \\
(16.02)\end{array}$ & $\begin{array}{c}45.51 \\
(16.19)\end{array}$ & $\begin{array}{c}48.25 \\
(13.22)\end{array}$ \\
\hline
\end{tabular}

$* *(*)$ Denotes statistical significance at the $\mathrm{p}<0.05(\mathrm{p}<.10)$ level; Cell entries provide parameter estimates for a linear random effects regression with the associated standard errors in parentheses. 
Table 3: Experimental Design - Laboratory Markets

\begin{tabular}{|c|c|}
\hline Resale Structure & Market Summary \\
\hline & $N R$ \\
No Resale & 5 bidders \\
& $\mathrm{N}=30$ \\
\hline Resale - OA Continuation: & $R O A$ \\
Resale price = High use value & $5 \mathrm{bidders}$ \\
\hline Resale - EA Continuation: & $\mathrm{N}=30$ \\
Resale price = Second highest use & $R E A$ \\
value & $5 \mathrm{bidders}$ \\
\hline
\end{tabular}

Notes: Each cell represents one unique treatment in which we gathered data in different sessions. For example, "NR" in row 1, column 2, denotes that the no-resale treatment had 30 subjects in groups of 5 competing in auction markets where ex post resale of the commodity was prohibited. No subject participated in more than one treatment.

Table 4: Bidder Signals and Use Values (in dollars)

\begin{tabular}{c|cccccccccc}
\hline & & & & & & & & & \\
& Pd. 1 & Pd. 2 & Pd. 3 & Pd. 4 & Pd. 5 & Pd. 6 & Pd. 7 & Pd. 8 & Pd. 9 & Pd. 10 \\
\hline $\begin{array}{c}\text { Buyer } \\
1\end{array}$ & 36 & 9 & 25 & 36 & 14 & 14 & 44 & 32 & 40 & 23 \\
& $(29)$ & $(19)$ & $(26)$ & $(37)$ & $(13)$ & $(21)$ & $(39)$ & $(24)$ & $(33)$ & $(17)$ \\
Buyer & 17 & 4 & 14 & 42 & 36 & 10 & 25 & 29 & 32 & 44 \\
2 & $(27)$ & $(12)$ & $(19)$ & $(32)$ & $(38)$ & $(14)$ & $(34)$ & $(22)$ & $(24)$ & $(40)$ \\
Buyer & 19 & 41 & 20 & 32 & 39 & 32 & 22 & 25 & 22 & 26 \\
3 & $(18)$ & $(36)$ & $(12)$ & $(29)$ & $(31)$ & $(39)$ & $(23)$ & $(17)$ & $(22)$ & $(34)$ \\
Buyer & 12 & 34 & 38 & 26 & 29 & 34 & 18 & 29 & 21 & 23 \\
$\quad 4$ & $(10)$ & $(26)$ & $(37)$ & $(20)$ & $(28)$ & $(34)$ & $(22)$ & $(39)$ & $(17)$ & $(25)$ \\
Buyer & 37 & 25 & 33 & 6 & 25 & 24 & 23 & 38 & 35 & 28 \\
5 & $(36)$ & $(33)$ & $(34)$ & $(13)$ & $(21)$ & $(28)$ & $(14)$ & $(33)$ & $(40)$ & $(23)$ \\
\hline
\end{tabular}

Notes: Each cell entry represents the signal received by the bidder in a given period and her induced use value (in parentheses). For example, buyer \#1 received a signal of $\$ 36.00$ and an induced use value of $\$ 29.00$ in market period 1 (column 2, row 2). Each buyer received the high signal in 2 of the market periods and the high use value in 2 of the market periods. In five of the market periods $(4,5,6,8$, and 9$)$ we would ex ante predict resale exchange, as the agent who received the high signal did not receive the high induced use value. 
Table 5: Mean Performance Measures-Lab Markets

\begin{tabular}{r|cccccccccc}
\hline & Pd & Pd & Pd & Pd & Pd & Pd & Pd & Pd & Pd & Pd \\
\hline No Resale & 1 & 2 & 3 & 4 & 5 & 6 & 7 & 8 & 9 & 10 \\
Avg. Bid & $\$ 20.84$ & $\$ 20.07$ & $\$ 24.31$ & $\$ 26.42$ & $\$ 27.68$ & $\$ 22.35$ & $\$ 24.80$ & $\$ 29.51$ & $\$ 28.03$ & $\$ 28.31$ \\
& $(9.32)$ & $(12.74)$ & $(7.13)$ & $(10.02)$ & $(8.12)$ & $(8.89)$ & $(9.56)$ & $(3.40)$ & $(6.17)$ & $(7.36)$ \\
Win Bid & $\$ 30.77$ & $\$ 36.63$ & $\$ 33.00$ & $\$ 35.55$ & $\$ 35.47$ & $\$ 32.23$ & $\$ 37.77$ & $\$ 34.10$ & $\$ 34.15$ & $\$ 37.25$ \\
& $(3.17)$ & $(3.07)$ & $(3.87)$ & $(1.58)$ & $(0.82)$ & $(2.64)$ & $(1.52)$ & $(2.14)$ & $(1.21)$ & $(2.27)$ \\
Resale & $\mathrm{N} / \mathrm{A}$ & $\mathrm{N} / \mathrm{A}$ & $\mathrm{N} / \mathrm{A}$ & $\mathrm{N} / \mathrm{A}$ & $\mathrm{N} / \mathrm{A}$ & $\mathrm{N} / \mathrm{A}$ & $\mathrm{N} / \mathrm{A}$ & $\mathrm{N} / \mathrm{A}$ & $\mathrm{N} / \mathrm{A}$ & $\mathrm{N} / \mathrm{A}$ \\
Price & & & & & & & & & & \\
OA & & & & & & & & & & \\
Avg. Bid & & & & & & & & & & \\
& $\$ 26.97$ & $\$ 25.86$ & $\$ 30.24$ & $\$ 29.10$ & $\$ 31.80$ & $\$ 30.64$ & $\$ 32.47$ & $\$ 35.57$ & $\$ 33.75$ & $\$ 34.39$ \\
Win Bid & $(7.49)$ & $(9.38)$ & $(5.46)$ & $(9.97)$ & $(6.98)$ & $(7.25)$ & $(5.38)$ & $(2.86)$ & $(7.58)$ & $(5.41)$ \\
& $\$ 35.68$ & $\$ 37.18$ & $\$ 36.92$ & $\$ 36.73$ & $\$ 38.68$ & $\$ 36.55$ & $\$ 38.02$ & $\$ 37.87$ & $\$ 38.15$ & $\$ 39.30$ \\
Resale & $(4.94)$ & $(2.55)$ & $(3.94)$ & $(2.47)$ & $(1.22)$ & $(2.06)$ & $(1.91)$ & $(1.52)$ & $(1.66)$ & $(1.08)$ \\
Price & $\$ 36$ & $\$ 36$ & $\$ 37$ & $\$ 37$ & $\$ 38$ & $\$ 39$ & $\$ 39$ & $\$ 39$ & $\$ 40$ & $\$ 40$ \\
& & & & & & & & & & \\
EA & & & & & & & & & & \\
Avg. Bid & $\$ 24.06$ & $\$ 21.55$ & $\$ 24.11$ & $\$ 26.26$ & $\$ 26.69$ & $\$ 22.11$ & $\$ 26.51$ & $\$ 29.63$ & $\$ 26.77$ & $\$ 26.96$ \\
Win Bid & $(9.72)$ & $(12.47)$ & $(10.48)$ & $(9.31)$ & $(7.78)$ & $(10.99)$ & $(7.86)$ & $(6.53)$ & $(7.63)$ & $(9.27)$ \\
Resale & $\$ 35.48$ & $\$ 36.25$ & $\$ 35.25$ & $\$ 36.27$ & $\$ 33.52$ & $\$ 32.00$ & $\$ 34.68$ & $\$ 36.35$ & $\$ 33.17$ & $\$ 34.67$ \\
Price & $(2.94)$ & $(3.97)$ & $(4.37)$ & $(3.34)$ & $(1.54)$ & $(3.74)$ & $(3.25)$ & $(3.48)$ & $(1.75)$ & $(3.22)$ \\
& $\$ 29$ & $\$ 33$ & $\$ 34$ & $\$ 32$ & $\$ 32$ & $\$ 34$ & $\$ 34$ & $\$ 33$ & $\$ 33$ & $\$ 34$ \\
& & & & & & & & & & \\
\hline
\end{tabular}

Note: Entries in the table provide mean performance measures across our three experimental treatments. The data are summarized by period and can be read as follows: in period 1 of the No Resale treatment the average bid was $\$ 20.84$ with a standard deviation of $\$ 9.32$. The average winning bid for the round was $\$ 30.77$ with a standard deviation of $\$ 3.17$. 
Table 6: Random Effects Regression - Lab Bid Levels

\begin{tabular}{|c|c|c|c|c|}
\hline & Model A & Model B & Model C & Model D \\
\hline Constant & $\begin{array}{c}21.93 * * \\
(1.02)\end{array}$ & $\begin{array}{c}16.58^{* *} \\
(0.97)\end{array}$ & $\begin{array}{c}16.44^{* *} \\
(1.68)\end{array}$ & $\begin{array}{l}8.72 * \\
(4.98)\end{array}$ \\
\hline OA Treatment & $\begin{array}{l}5.85^{* *} \\
(0.92)\end{array}$ & & $\begin{array}{c}13.54^{* *} \\
(1.44)\end{array}$ & $\begin{array}{c}13.06^{* *} \\
(1.41)\end{array}$ \\
\hline EA Treatment & $\begin{array}{c}0.23 \\
(0.92) \\
\end{array}$ & & $\begin{array}{l}6.28 * * \\
(1.44) \\
\end{array}$ & $\begin{array}{l}5.48^{* *} \\
(1.48) \\
\end{array}$ \\
\hline EA Treatment and Signal $<\$ 26.00$ & & $\begin{array}{c}2.38^{* *} \\
(1.06)\end{array}$ & & \\
\hline OA Treatment and Signal $<\$ 26.00$ & & $\begin{array}{l}8.47 * * \\
(1.06)\end{array}$ & & \\
\hline NR Treatment and Signal $\geq \$ 26.00$ & & $\begin{array}{c}12.69^{* *} \\
(0.74)\end{array}$ & & \\
\hline EA Treatment and Signal $\geq \$ 26.00$ & & $\begin{array}{c}10.61^{* *} \\
(1.08)\end{array}$ & & \\
\hline OA Treatment and Signal $\geq \$ 26.00$ & & $\begin{array}{c}15.70^{* *} \\
(1.08)\end{array}$ & & \\
\hline Risk_Signal & & & $\begin{array}{l}0.20^{* *} \\
(0.02)\end{array}$ & $\begin{array}{l}0.14 * * \\
(0.03)\end{array}$ \\
\hline Risk_Signal2 & & & $\begin{array}{c}-0.001 \\
(0.0003)\end{array}$ & $\begin{array}{l}-0.001 * * \\
(0.0003)\end{array}$ \\
\hline OA_Risk_Signal & & & $\begin{array}{l}-0.06^{* *} \\
(0.008)\end{array}$ & $\begin{array}{l}-0.05^{* *} \\
(0.008)\end{array}$ \\
\hline EA_Risk_Signal & & & $\begin{array}{l}-0.04 * * \\
(0.008)\end{array}$ & $\begin{array}{l}-0.04 * * \\
(0.008)\end{array}$ \\
\hline Signal_MeanRisk & & & & $\begin{array}{l}0.12 * * \\
(0.01)\end{array}$ \\
\hline $\begin{array}{l}\text { Risk_Signal__ } \\
\text { MeanRisk }\end{array}$ & & & & $\begin{array}{l}-0.01 * * \\
(0.005)\end{array}$ \\
\hline Individual Risk & & & $\begin{array}{c}-2.94^{* *} \\
(0.33)\end{array}$ & \\
\hline MeanRisk & & & & $\begin{array}{l}-1.61^{*} \\
(0.96) \\
\end{array}$ \\
\hline Period Fixed Effects & Yes & Yes & Yes & Yes \\
\hline Bidder Random Effects & Yes & Yes & Yes & Yes \\
\hline \# of Bidders & 90 & 90 & 90 & 90 \\
\hline Number of Observations & 900 & 900 & 900 & 900 \\
\hline Sigma_U & 2.51 & 3.06 & 4.49 & 3.24 \\
\hline Sigma_E & 7.93 & 6.26 & 5.65 & 5.32 \\
\hline Log Likelihood & -3171.53 & -2983.21 & -2924.98 & -2851.86 \\
\hline
\end{tabular}

Note: Cell entries indicate the marginal effect of model covariates (see text for description of covariates) on recorded bid level. For example, in row 2 of Column A the estimated marginal effect of being in the OA treatment is an increase of $\$ 5.85$ on bids, ceteris paribus. 
Table 7: Signal and Bid Order - All Rounds

\begin{tabular}{|r|c|c|c|c|c|}
\hline & Highest Bid & $\begin{array}{c}2^{\text {nd }} \text { Highest } \\
\text { Bid }\end{array}$ & $\begin{array}{c}3^{\text {rd }} \text { Highest } \\
\text { Bid }\end{array}$ & $\begin{array}{c}4^{\text {th }} \text { Highest } \\
\text { Bid }\end{array}$ & Lowest Bid \\
\hline No Resale & & & & & $0 \%$ \\
\hline Highest Signal & $80 \%$ & $18.3 \%$ & $1.7 \%$ & $0 \%$ \\
\hline $2^{\text {nd }}$ Highest Signal & $13.3 \%$ & $46.7 \%$ & $26.7 \%$ & $10 \%$ & $3.3 \%$ \\
\hline $3^{\text {rd }}$ Highest Signal & $6.7 \%$ & $26.7 \%$ & $55 \%$ & $8.3 \%$ & $3.3 \%$ \\
\hline $4^{\text {th }}$ Highest Signal & $0 \%$ & $6.7 \%$ & $11.7 \%$ & $50 \%$ & $31.7 \%$ \\
\hline Lowest Signal & $0 \%$ & $1.7 \%$ & $5 \%$ & $31.7 \%$ & $61.7 \%$ \\
\hline $\boldsymbol{O A}$ Treatment & & & & & \\
\hline Highest Signal & $51.7 \%$ & $25 \%$ & $13.3 \%$ & $8.3 \%$ & $1.7 \%$ \\
\hline $2^{\text {nd }}$ Highest Signal & $20 \%$ & $31.7 \%$ & $16.7 \%$ & $21.7 \%$ & $10 \%$ \\
\hline $3^{\text {rd }}$ Highest Signal & $11.7 \%$ & $21.7 \%$ & $33.3 \%$ & $21.7 \%$ & $11.7 \%$ \\
\hline $4^{\text {th }}$ Highest Signal & $11.7 \%$ & $8.3 \%$ & $23.3 \%$ & $28.3 \%$ & $28.3 \%$ \\
\hline Lowest Signal & $5 \%$ & $13.3 \%$ & $13.3 \%$ & $20 \%$ & $48.3 \%$ \\
\hline $\boldsymbol{E A}$ Treatment & & & & & \\
\hline Highest Signal & $43.3 \%$ & $31.7 \%$ & $13.3 \%$ & $5 \%$ & $6.7 \%$ \\
\hline $2^{\text {nd }}$ Highest Signal & $30 \%$ & $28.3 \%$ & $21.7 \%$ & $11.7 \%$ & $8.3 \%$ \\
\hline $3^{\text {rd }}$ Highest Signal & $15 \%$ & $20 \%$ & $31.7 \%$ & $23.3 \%$ & $10 \%$ \\
\hline $4^{\text {th }}$ Highest Signal & $10 \%$ & $11.7 \%$ & $23.3 \%$ & $31.7 \%$ & $23.3 \%$ \\
\hline Lowest Signal & $1.7 \%$ & $8.3 \%$ & $10 \%$ & $28.3 \%$ & $51.7 \%$ \\
\hline
\end{tabular}

Note: Cell entries are frequencies and can be read as follows - in our baseline treatment the bidder with the highest signal submits the highest bid $80 \%$ of the time.

Table 8: Signal Order and the Likelihood of Winning the Auction

\begin{tabular}{|l|c|c|}
\hline & Probability of Winning & Probability of Winning \\
\hline Constant - Baseline Treatment & $0.74^{* *}$ & $-1.57^{* *}$ \\
& $(0.20)$ & $(0.13)$ \\
\hline Indicator for OA Treatment & $-0.70^{* *}$ & $0.39^{* *}$ \\
& $(0.27)$ & $(0.17)$ \\
\hline Indicator for EA Treatment & $-0.91^{* *}$ & $0.49^{* *}$ \\
& $(0.27)$ & $(0.16)$ \\
\hline & & 2 \\
\hline Signal Order & Highest Signal Only & $2^{\text {nd }}$ Highest to Lowest Signal \\
\hline Session Random Effects & Yes & Yes \\
\hline & 180 & -239.7 \\
\hline \# of Observations & -115.04 & 720 \\
\hline Log Likelihood & \multicolumn{2}{|c|}{$*$ Denotes statistical significance at the $\mathrm{p}<0.01$ level }
\end{tabular}

Note: Cell entries are parameter estimates from a random effects probit model examining the factors that influence the likelihood of submitting the winning bid. Standard errors are in parentheses. Column A restricts the sample to only those bidders who received the highest signal in the auction. Column B restricts the sample to only those bidders who received higher order signals - i.e., the second highest to the lowest signal. 


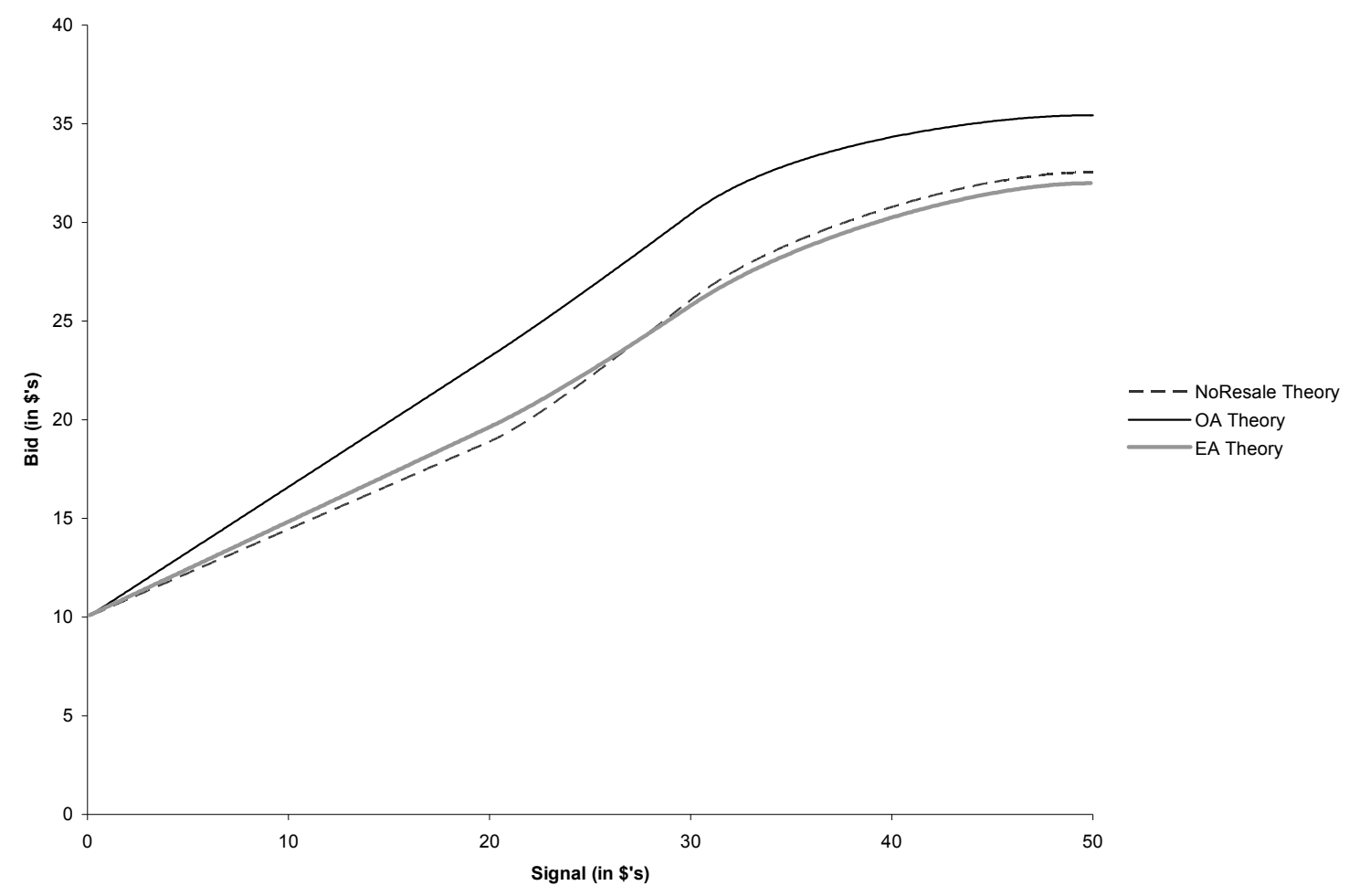

Figure 1: Risk-Neutral Predictions for Bids

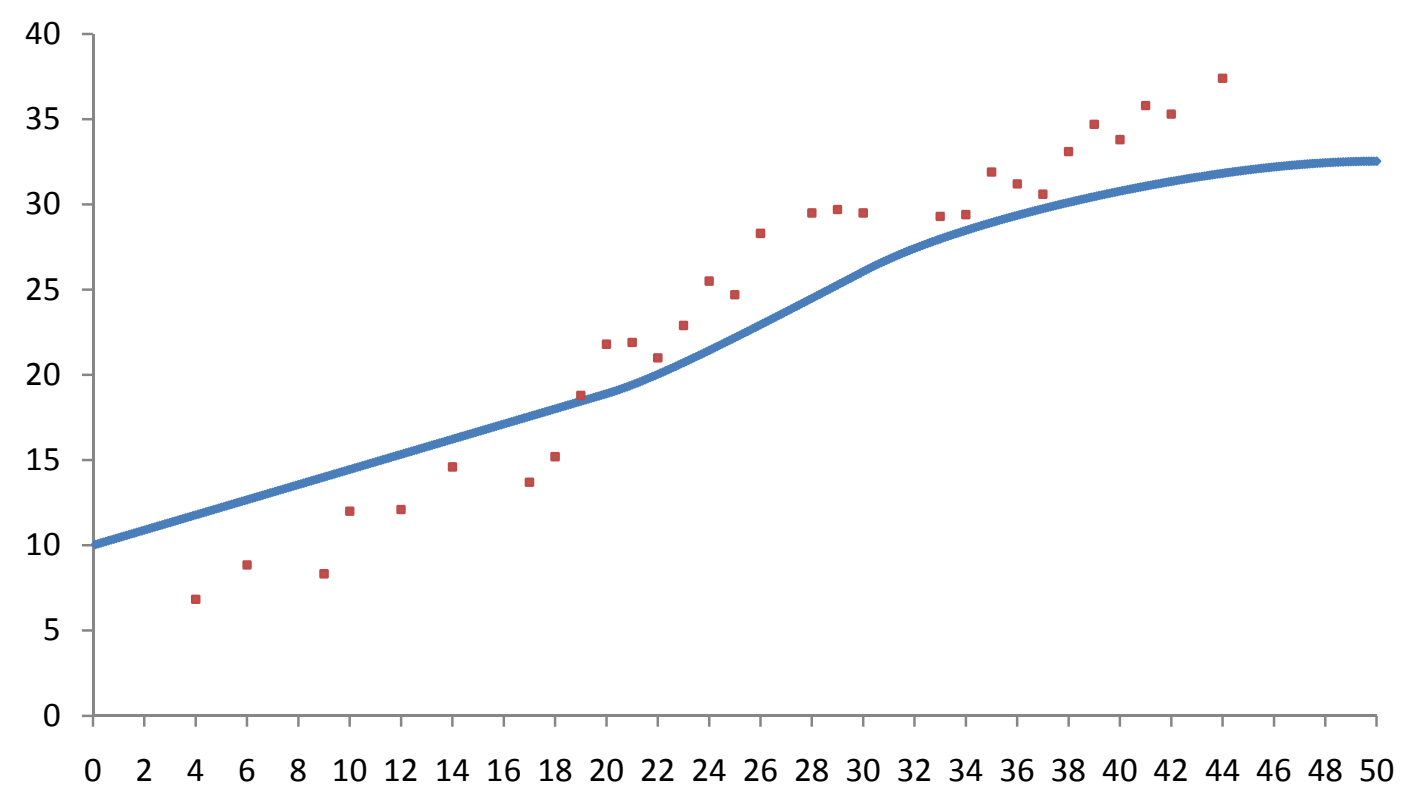

Figure 2: Average Bid by Signal - Baseline Treatment 


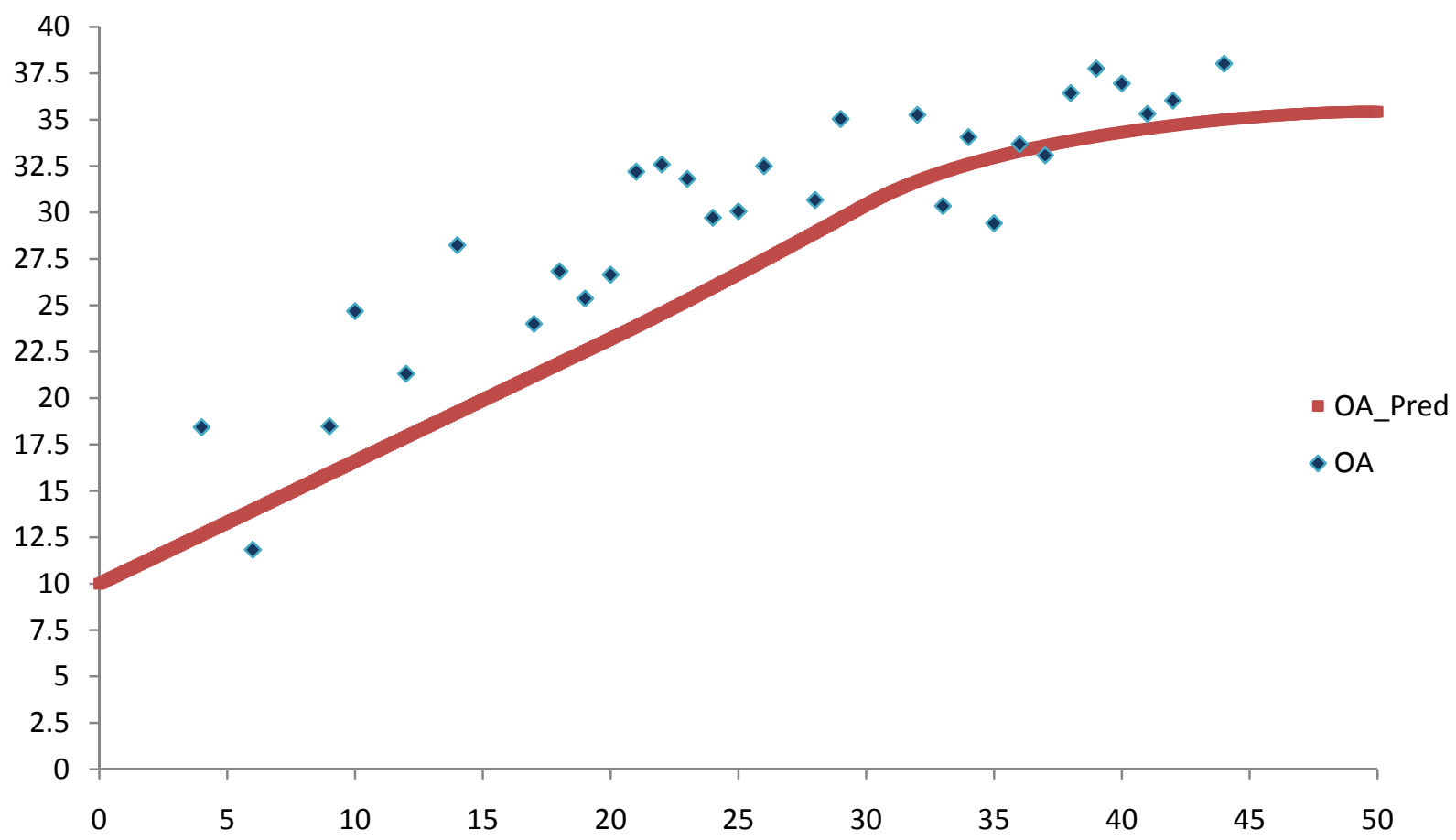

Figure 3: Average Bid by Signal - OA Treatment

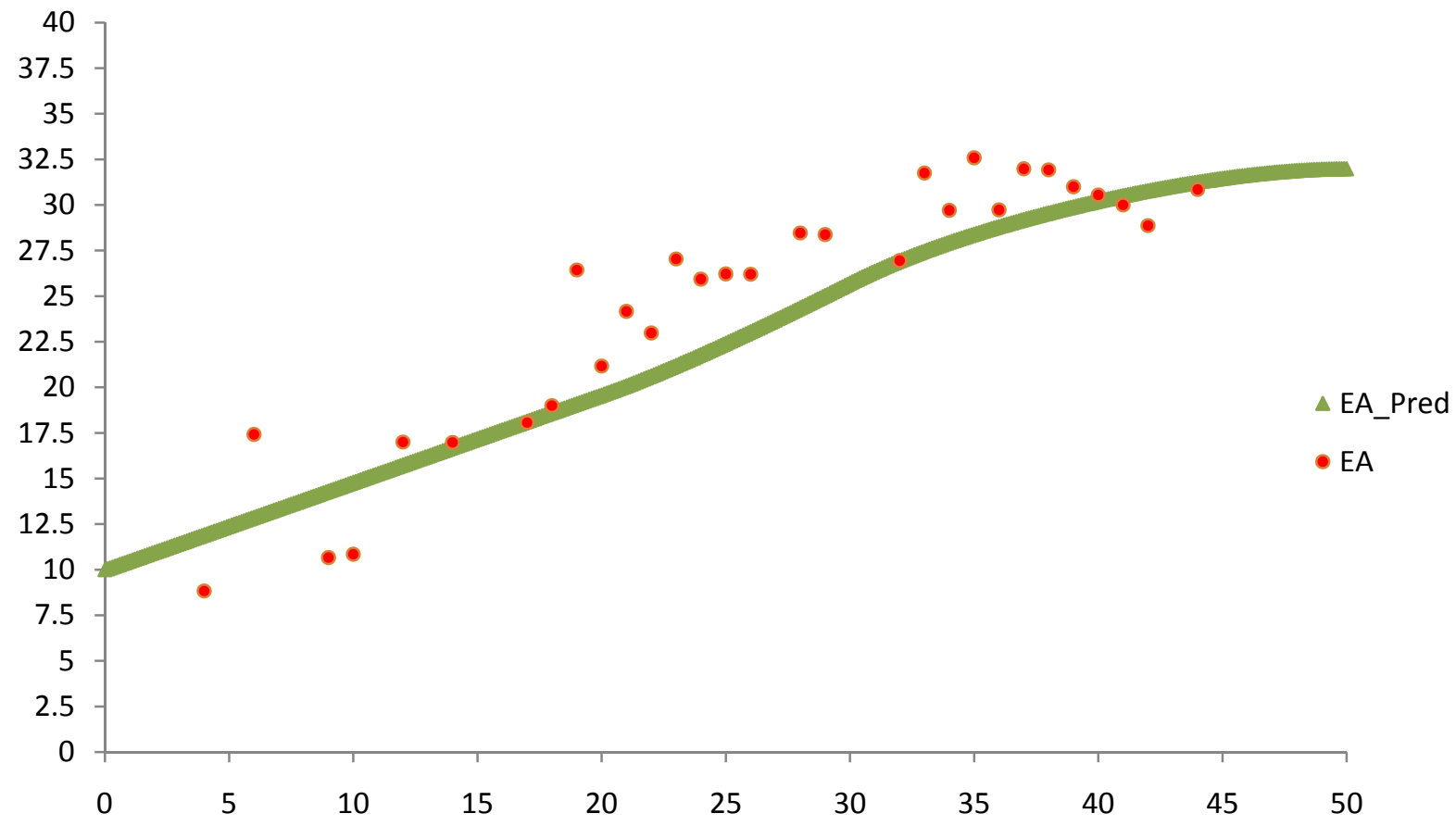

Figure 4: Average Bid by Signal - EA Treatment 


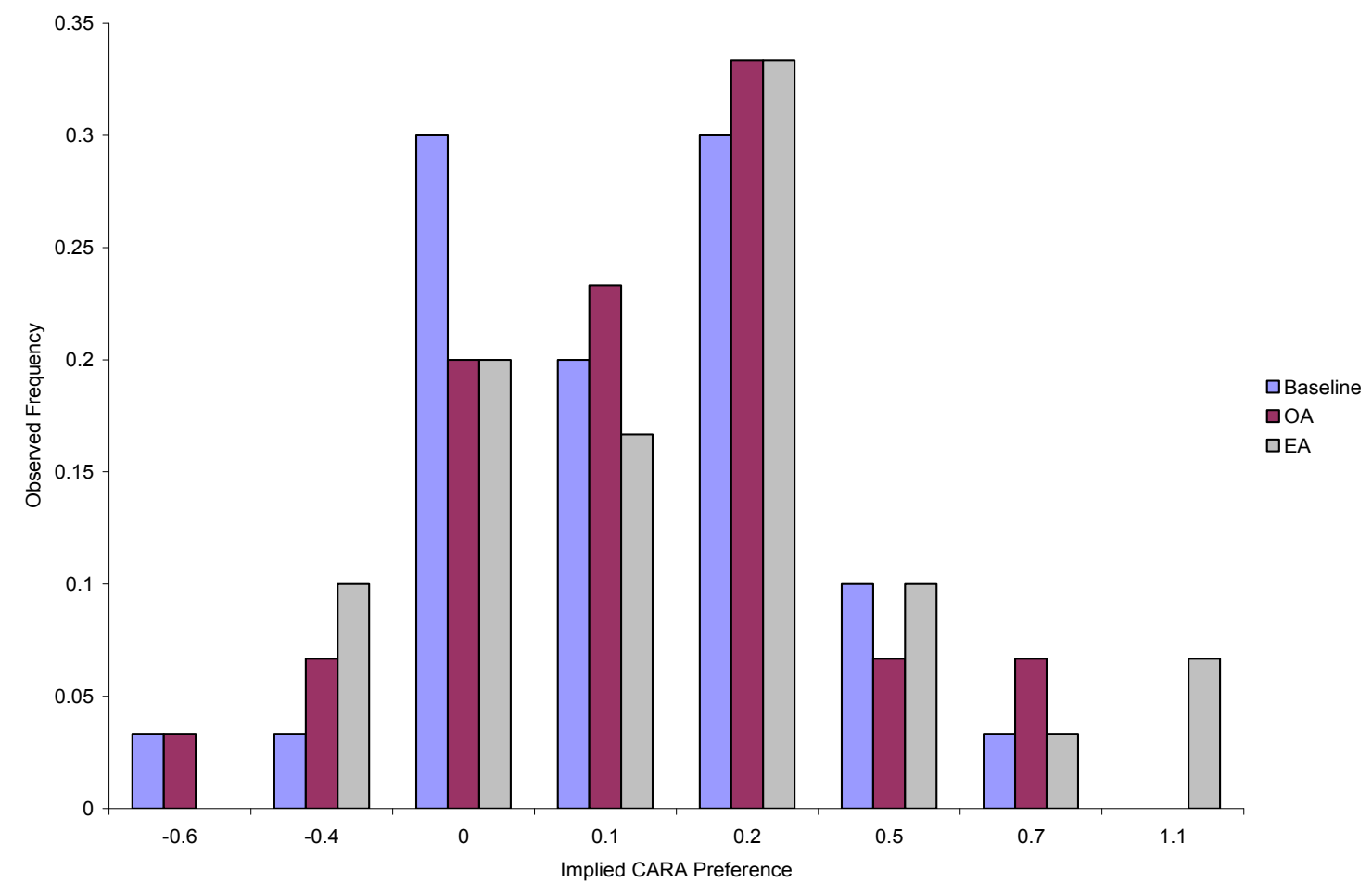

Figure 5: Frequency Distribution of CARA Preferences by Treatment 
Welcome to Lister's Auctions! You have the opportunity to bid in a series of experimental auctions today and you can earn cash by participating.

\section{Auction Rules:}

In this auction you will bid against four (4) other people and the person with the highest bid is the winner, and pays the amount of their bid for the "fictitious" commodity. The auction is a sealed bid auction so you don't know the bids of the other participants. We will repeat the auction for 10 rounds. At the end of the session, your earnings from this experiment and another unrelated experiment will be summed and paid to you in cash.

There are six steps in the auction process, each of which is explained in detail below. The six steps include: (i) determining your signal of the value of the fictitious commodity, (ii) determining your bid, (iii) determining your use value for the fictitious good, (iv) determining the winner, (v) the resale market, and (vi) determining your payouts for the round.

1. Determining your signal of the good's value: At the beginning of each period, a monitor will hand you a card numbered from zero dollars $(\$ 0)$ to fifty dollars $(\$ 50)$ in one dollar (\$1) increments. The value on the card handed to you will be a signal of your use value for the fictitious good. The other bidders in your auction will have their signals determined in exactly the same way. Signals are private and independent across buyers, and your signal will change across rounds.

\section{Signals and Use Values}

Use values, $\mathrm{V}$, in each round are drawn from a uniform distribution on the interval [10, 40]. That is, every dollar value between 10 and 40 is equally likely to be drawn as your use value. These values are independently drawn for each subject and will differ across periods.

The signal you will receive is determined by adding a random number drawn on the interval $[-10,10]$ to your use value. Again, each dollar value between -10 and 10 is equally likely to be drawn and added to your use value. Your first-stage signal, $\mathrm{S}$, is hence given by:

$$
S=V+\text { random number }
$$

Your signal, $\mathrm{S}$, is thus distributed on the interval $[\$ 0, \$ 50]$.

Given your signal, you can compute the expected use value. For example, if you were to receive a signal of $\$ 30$ in the first stage, you know that your final use value must lie somewhere in the interval $[\$ 20, \$ 40]$. Since each of these values is equally likely to have been selected as your use value, on average your use value is $\$ 30$. However, any value in this range could have been assigned as your use value. 
2. Determining your bid value: After receiving your signal, you will choose your bid value for the fictitious good. In order to choose your bid, consider how your earnings for each period are calculated. If you are the person with the highest bid you are the winner of the auction. Your earnings are equal to your use value minus your bid amount if you have the highest end use value:

\section{Earnings $=$ your good's use value $(V)-$ your bid}

If you are the person with the highest bid but do not have the highest use value, your earnings are equal to the highest use value of all participants minus your bid amount:

\section{Earnings $=$ highest use value - your bid}

If you are not the high bidder in a round, your earnings for the period are zero. If there is a tie, the winner will be determined by the flip of a coin (if more than two people tie we will draw a card to determine the winner). Your bid can be any amount in the range from zero $(\$ 0)$ to forty dollars $(\$ 40)$ in ten cent $(\$ 0.10)$ increments.

3. Determining your use value: Once all bids have been received, a monitor will hand you a second slip of paper numbered from ten dollars $(\$ 10)$ to forty dollars $(\$ 40)$ that gives your final use value, $V$. Your use value will lie within $\pm \$ 10$ of your signal, $S$.

4. Determining the auction winner: All bids will be publicly announced and recorded by a monitor on the blackboard. Your bid will be compared with those of the four other participants in the auction. The person with the highest bid amount is the winner.

5. The resale market: In the resale market, each participant can see the use values for all other participants. The highest bidder in the auction market will sell the "fictitious" commodity to the individual with the highest use value. In this experiment this happens automatically. The payoff for the winner is the highest use value of all participants minus his/her bid amount. If you did not win the auction, your payout for the period will be zero. The payout for the auction winner can be positive even if your bid was greater than your use value.

6. Determining your payouts: If you are the auction winner, you will receive the difference between the highest use value and your bid. If you did not win the auction, you receive zero for that period. Your total earnings for this experiment are the sum of your earnings for each of the 10 periods.

Do you have any questions about the auction process? 
Record your subject number from the previous part on your decision sheet. Your decision sheet shows ten decisions listed on the left. Each decision is a paired choice between OPTION A and OPTION B. You will make ten choices and record these in the final column, but only one of them will be used in the end to determine your earnings. Before you start making your ten choices, please let me explain how these choices will affect your earnings for this part of the experiment.

We will use part of a deck of cards to determine payoffs; cards 2-10 and the Ace will represent " 1 ". After you have made all of your choices, we will randomly select a card twice, once to select one of the ten decisions to be used, and a second time to determine what your payoff is for the option you chose, A or B, for the particular decision selected. (After the first card is selected, it will be put back in the pile, the deck will be reshuffled, and the second card will be drawn.) Even though you will make ten decisions, only one of these will end up affecting your earnings, but you will not know in advance which decision will be used. Obviously, each decision has an equal chance of being used in the end.

Now, please look at Decision 1 at the top. OPTION A pays $\$ 2.00$ if the Ace is selected, and it pays $\$ 1.60$ if the card selected is $2-10$. OPTION B yields $\$ 3.85$ if the Ace is selected, and it pays $\$ 0.10$ if the card selected is $2-10$. The other decisions are similar, except that as you move down the table, the chances of the higher payoff for each option increase. In fact, for Decision 10 in the bottom row, the cards will not be needed since each option pays the highest payoff for sure, so your choice here is between $\$ 2.00$ or $\$ 3.85$.

To summarize, you will make ten choices: for each decision row you will have to choose between OPTION A and OPTION B. You may choose A for some decision rows and B for other rows, and you may change your decisions and make them in any order. When you are finished, we will come to your desk and pick a card to determine which of the ten decisions will be used. Then we will put the card back in the deck, shuffle, and select a card again to determine your money earnings for the OPTION you chose for that decision. Earnings for this choice will be added to your previous earnings, and you will be paid all earnings in cash when we finish.

So now please look at the empty boxes on the right side of the record sheet. You will have to write a decision, A or B in each of these boxes, and then the card selection will determine which one is going to count. We will look at the decision that you made for the choice that counts, and circle it, before selecting a card again to determine your earnings for this part. Then you will write your earnings in the blank at the bottom of the page.

Are there any questions? Now you may begin making your choices. Please do not talk with anyone else while we are doing this; raise your hand if you have a question. 